\title{
PERAN PROGRAM STUDI KEWIRAUSAHAAN DI PERBATASAN DALAM MENGHADAPI ERA REVOLUSI INDUSTRI 4.0 (Studi Kasus: Kabupaten Bengkayang-Kalimantan Barat)
}

\author{
Sabinus Beni ${ }^{1)}$ dan Yosua Damas Sadewo ${ }^{2)}$ \\ ${ }^{1,2}$ Program Studi Kewirausahaan, Sekolah Tinggi Ilmu Manajemen Shanti Bhuana \\ 1,2, Jalan Bukit Karmel No.1, Bengkayang, 79211 \\ E-mail : sabinusbeni@gmail.com ${ }^{1)}$, yosua@ shantibhuana.ac.id ${ }^{2)}$
}

\begin{abstract}
ABSTRAK
Revolusi industri keempat (Era 4.0) dicirikan oleh kompleksnya persoalan yang akan dihadapi penduduk dunia. Semua jenis pekerjaan akan semakin kompleks. Hal ini disebabkan kombinasi globalisasi dengan teknologi informasi yang kecepatan perkembangannya sangat di luar dugaan. Salah satu persoalan dewasa ini adalah penciptaan lapangan kerja dan salah satu peluang industri 4.0 yaitu integrasi Usaha Kecil Menengah dan kewirausahaan. Program Studi Kewirausahaan menjadi salah satu solusi dalam menyiapkan sumber daya manusia dalam menghadapi revolusi industri keempat. Daerah perbatasan merupakan garda terdepan dalam menggambarkan kemajuan suatu bangsa, program studi kewirausahaan menjawab semua permasalahan dalam proses pembangunan perbatasan. Dengan hadirnya program studi kewirausahaan di perbatasan Kabupaten Bengkayang sangat mendapatkan apresisasi dari masyarakat dan pemerintah, dimana kelak lulusannya dapat menjadi para entrepreneur maupun intrapreneur yang secara tidak langsung dapat meningkatakan rasa nasionalisme dan jiwa patriotik masyarakat perbatasan dikarenakan masyarakat sudah sejahtera dan tidak mengandalkan malaysia (Sarawak) sebagai temapat untuk mencari pekerjaan. Penelitian ini menggunakan metode Deskriptif yang dilakukan di perbatasan Indonesia (Kabupaten Bengkayang-Kalimantan Barat) dengan Malaysia (Sarikin-Sarawak) dengan mayoritas penduduknya sebagai petani dan sepenuhnya bergantung kepada Malaysia untuk pemasaran hasil-hasil pertanian dan perkebunan.hasil penelitian menunjukkan bahwa peran program studi kewirausahaan memberikan dampak sangat besar bagi perubahan masyarakat perbatasan, dimana pada awalnya masih berorientasi pada produk bahan baku yang langsung dijual ke Malaysia berubah kearah penambahan nilai tambah produk yang dapat meningkatkan pendapatan.
\end{abstract}

Kata Kunci: Perbatasan, Kewirausahaan, Era 4.0., Pembangunan, Kemiskinan.

\section{PENDAHULUAN}

Revolusi Industri keempat atau era revolusi industri 4.0 akan menciptakan model bisnis dan industri yang baru. Dalam menciptakan model bisnis dan industri yang baru diperlukan sumber daya manusia yang peka terhadap perubahan situasi yang sedang terjadi saat ini dan saat yang akan datang terutama sumber daya manusia yang memiliki jiwa wirausaha atau berjiwa bisnis.

Kondisi yang ada saat ini didaerah pedalaman kalimantan barat dimana sumber daya masyarakatnya bisa dikatakan cukup baik, tetapi masih atau mayoritas berjiwa/mental konsumtif dan sebagai tenaga kerja bukannya sebagai pengguna tenaga kerja. Mengatasi hal tersebut mendesak dan sangat pentingnya peran perguruan tinggi yang memiliki program studi kewirausahaan untuk mencetak para entrepreneurs/Wirausaha muda sehingga menjadi aktor utama dalam menghadapi revolusi industri era 4.0 khususnya di Kalimantan Barat yang berbatasan langsung dengan Negara Malaysia bagian Sarawak.

Definisi mengenai Industri 4.0 beragam karena masih dalam tahap penelitian dan pengembangan. Kanselir
Jerman, Angela Merkel dalam penelitian Hoedi Prasetyo dan Wahyudi Sutopo (2018) yang berjudul Industri 4.0: Telaah Klasifikasi Aspek dan Arah Perkembangan Riset, berpendapat bahwa Industri 4.0 adalah transformasi komprehensif dari keseluruhan aspek produksi di industri melalui penggabungan teknologi digital dan internet dengan industri konvensional. Schlechtendahl dkk (2015) menekankan definisi kepada unsur kecepatan dari ketersediaan informasi, yaitu sebuah lingkungan industri di mana seluruh entitasnya selalu terhubung dan mampu berbagi informasi satu dengan yang lain.

Revolusi industri keempat membawa berbagai dampak dari beberapa aspek, dan aspek utama yang paling berdampak adalah pada bidang industri dan manufaktur, namun dampak pada bidang lain yang terpengaruh diantaranya terjadi pada bidang kesehatan, pemerintahan, ekonomi, dan masyarakat. Pada bidang ekonomi, aspek yang dipengaruhi secara besar adalah pada aspek bisnis. "Secara keseluruhan, ada empat efek utama yang dihadapi Revolusi Industri Keempat terhadap ekspektasi pelanggan bisnis, peningkatan produk, inovasi kolaboratif, dan bentuk organisasi." (Schwab, 2017). Maupun konsumen atau bisnis, 
pelanggan semakin berada di pusat ekonomi, ini semua berkaitan dengan peningkatan dalam bagaimana pelanggan dilayani. Produk dan layanan fisik, terlebih lagi, sekarang dapat ditingkatkan dengan kemampuan digital yang meningkatkan nilainya. Teknologi baru membuat aset lebih awet dan tangguh, sementara data dan analisis mengubah tampilannya. Dunia pengalaman pelanggan, layanan berbasis data, dan kinerja aset melalui analisis, sementara itu, memerlukan bentuk kolaborasi baru, terutama mengingat kecepatan di mana inovasi dan gangguan sedang terjadi. Dan kemunculan platform global dan model bisnis baru lainnya, akhirnya, berarti bahwa bakat, budaya, dan bentuk organisasi harus dipikirkan kembali.

Dalam tulisan Alfian Dally Irawan tahun yang berjudul: Revolusi Industri 4.0: Dampak dalam berbagai Aspek, menyatakan bahwa: Revolusi Industri Keempat, akhirnya, tidak hanya mengubah apa yang kita lakukan tapi juga siapa kita. Ini akan mempengaruhi identitas kita dan semua masalah yang terkait dengannya: rasa privasi, pengertian kepemilikan, pola konsumsi kita, waktu yang kita gunakan untuk bekerja dan bersenang-senang, dan bagaimana kita mengembangkan karir kita, menumbuhkan keterampilan kita, bertemu orang, dan memelihara hubungan." (Schwarb, 2017). Dari kutipan di atas juga menjelaskan bahwa revolusi industri 4.0 juga mempengaruhi masing-masing individu. Salah satu tantangan individu terbesar yang diajukan oleh teknologi informasi baru adalah privasi. Perdebatan tentang isu-isu mendasar seperti dampak pada kehidupan batin kita atas hilangnya kontrol atas data kita hanya akan meningkat di tahun-tahun mendatang.

Revolusi industri 4.0 memiliki pengaruh yang cukup besar terhadap berbagai aspek yang telah diterangkan. Pengaruh negatif maupun positif memberikan gambaran bahwa persiapan dalam menghadapi revolusi industri 4.0 yang sudah mulai terjadi haruslah matang dan tepat, karena persiapan yang kurang akan membawa dampak negatif bagi diri sendiri maupun orang - orang disekitar kita. Secara nyata revolusi industri keempat sudah terjadi, semua orang akan merasakan dampak yang ditimbulkan dari fenomena ini, baik yang telah mempersiapkannya maupun yang tidak memiliki kesiapan.

Dalam Pidato Prof. Dr. H. Muhammad Yahya, M.Kes., M.Eng. yang disampaikan pada sidang terbuka luar biasa senat Universitas Negeri Makassar pada acara pengukuhan penerimaan Jabatan Professor Tetap Dalam Bidang Ilmu Pendidikan Kejuruan Fakultas Teknik Universitas Negeri Makassar Yang Berjudul: Era Industri 4.0: Tantangan Dan Peluang Perkembangan Pendidikan Kejuruan Indonesia. Pemetaan tantangan dan peluang industri 4.0 untuk mencegah berbagai dampak dalam kehidupan masyarakat, salah satunya adalah permasalahan pengangguran. Work Employment and Social Outlook Trend 2017 memprediksi jumlah orang yang menganggur secara global pada 2018 diperkirakan akan mencapai angka 204 juta jiwa dengan kenaikan tambahan 2,7 juta. Hampir sama dengan kondisi yang dialami negara barat, Indonesia juga diprediksi mengalami hal yang sama. Pengangguran juga masih menjadi tantangan bahkan cenderung menjadi ancaman. Tingkat pengangguran terbuka Indonesia pada Februari 2017 sebesar 5,33\% atau 7,01 juta jiwa dari total 131,55 juta orang angkatan kerja (Sumber: BPS 2017).

Data BPS 2017 juga menunjukkan, jumlah pengangguran yang berasal dari Sekolah Menengah Kejuruan (SMK) menduduki peringkat teratas yaitu sebesar 9,27\%. Selanjutnya adalah lulusan Sekolah Menengah Atas (SMA) sebesar 7,03\%, Diploma III (D3) sebesar 6,35\%, dan universitas 4,98\%. Diidentifikasi, penyebab tingginya kontribusi pendidikan kejuruan terhadap jumlah pengangguran di Indonesia salah satunya disebabkan oleh rendahnya keahlian khusus dan soft skill yang dimiliki.

Permasalahan pengangguran dan daya saing sumber daya manusia menjadi tantangan yang nyata bagi Indonesia. Tantangan yang dihadapi Indonesia juga ditambah oleh tuntutan perusahaan dan industri. Bank Dunia (2017) melansir bahwa pasar kerja membutuhkan multi-skills lulusan yang ditempa oleh satuan dan sistem pendidikan, baik pendidikan menengah maupun pendidikan tinggi.

\section{RUANG LINGKUP}

Ruang lingkup penelitian ini adalah untuk menggambarkan tentang peran program studi kewirausahaan dalam menghadapi Era Revolusi Industri 4.0 di daerah perbatasan Indonesia (BengkayangKalimantan Barat) dengan Malaysia (Sarikin-Sarawak) dengan studi kasus pada Program Studi Kewirausahaan Sekolah Tinggi Ilmu Manajemen Shanti Bhuana.

\section{BAHAN DAN METODE}

Penelitian ini merupakan jenis penelitian kualitatif deskriptif, di mana data yang diperoleh dianalisis dengan mereduksi data yakni memilah data yang penting dan kemudian mendeskripsikannya. Penelitian ini dilakukan untuk mendeskripsikan fenomena yang terjadi dalam menghadapi revolusi industri keempat yang dapat menjadi salah satu solusi dalam menyiapkan sumber daya manusia era revolusi industri 4.0. Adapun data yang diperoleh melalui observasi lapangan, studi kepustakaan dan dokumen dari beberapa instansi yang terkait dengan penelitian dan hasil dari wawancara dengan beberapa sumber. Adapun studi dokumentasi yang dimaksud adalah dengan mengkaji dan menganalisis dokumendokumen mengenai Program Studi Kewirausahaan.

Penelitian (Abdul Hamid Kurniawan dan Tunggul Butar-Butar, Tahun 2019) tentang Evaluasi E-Learning STMIK Sentra Perndidikan Bisnis Airlangga Samarinda, menemukan bahwa E-learning merupakan salah satu cara melakukan inovasi pembelajaran yang efektif dan sudah banyak diterapkan di beberapa perguruan tinggi.

Penelitian Mohammad Salman Alfarisi tentang IPTEK bagi masyarakat: Penerapan IoT dengan 
Smartphone Pada SMK Plus Al-Musyarrofah Sebagai Upaya Pencapaian Sustainable Development Goal Tujuan 4 Target 3 menyatakan bahwa dengan tambahan pengetahuan IoT Siswa SMK Plus Al-Musyarrofah dapat memanfaatkan secara optimal smartphone dalam kegiatan belajar mengajar seperti IFTTT, Marcro Droid dan Tasker.

Penelitian Iskandar Agung tentang Kajian Penyelenggaraan Pendidikan Di Daerah Perbatasan menyatakan bahwa bahwa pada dasarnya kondisi pendidikan di daerah perbatasan cenderung memperihatinkan dan memerlukan perhatian serius dari berbagai pihak yang berkompeten. Upaya meningkatkan kualitas sumberdaya manusia di daerah perbatasan tidak akan terwujud apabila tidak disertai dengan peningkatan segenap aspek pendidikan di dalamnya. Sejumlah variabel latent eksogen dalam penelitian ini, seperti Masukan Siswa (MS), Sarana Prasarana (SP), Ketenagaan (KN), Biaya Pendidikan (BP), dan Kurikulum Pendidikan (KR), terbukti memiliki pengaruh signifikan terhadap variabel latent endogen Hasil Belajar (HB). Hasil penelitian ini menunjukkan, bahwa kondisi Wawasan Kebangsaan peserta didik berada pada kategori yang kurang memuaskan, dan diprediksi rentan terpengaruh oleh unsur asing. Rangsangan eksternal relatif mudah mempengaruhi kehidupan peserta didik/siswa daerah perbatasan, baik yang bersifat ideologis, politis, ekonomis, sosial-budaya, maupun pertahanan-keamanan.

Penelitian Sabinus Beni dan Blasius Manggu tentang Program Keluarga Harapan Dalam Menumbuhkan Jiwa Wirausaha menyatakan bahwa Program Keluarga Harapan (PKH) cukup baik untuk menumbuhkan jiwa wirausaha masyarakat pra sejahtera melalui kelompok usaha bersama (KUBE) tetapi belum optimal dikarenakan kurang kompetennya pendamping sosial dalam bidang wirausaha yang tentunya menjadi peluang bagi program studi kewirausahaan untuk mengisi celah tersebut dalam rangka membantu pemerintah mengurangi angka kemiskinan dan pengangguran di perbatasan dengan menciptakan wirausaha baru bagi keluarga pra sejahtera.

Penelitian Yosua Damas Sadewo tentang Hambatan dan Tantangan Program Studi Kewirausahaan Di Wilayah Perbatasan menyatakan bahwa kehadiran program studi kewirausahaan dengan segala kekurangan dan keterbatasan di perbatasan merupakan angin segar untuk dapat membawa perubahan bagi masyarakat perbatasan Bengkayang yang selama ini terpinggirkan dan jauh dari sentuhan pemerintah pusat. Program studi kewirausahaan berupaya mewujudkan mimpi masyarakat perbatasan untuk segera lepas landas dari kemiskinan dan siap menjadi wirausahawan baru yang tidak lagi tergantung terhadap kemurahan alam dan siap menjadi tuan rumah di negeri sendiri.

Penelitian ini dilakukan dengan studi pendahuluan melalui kajian pustaka terkait dengan program pemberdayaan masyarakat perbatasan yang dilanjutkan dengan observasi lapangan ke Perbatasan Jagoi Babang dengan Sarikin Malaysia untuk melakukan wawancara dengan penduduk sekitar terutama masyarakat penerima bantuan Program Keluarga Harapan (PKH) untuk menggali tentang pentingnya peran program studi kewirausahaan serta dilakukan wawancara dengan pemerintah kabupaten bengkayang, orang tua mahasiswa serta masyarakat pemerhati perbatasan. Hasil studi lapangan dan wawancara dianalisa dengan mendeskripsikanny yang dituangkan dalam bentuk artikel ilmiah yang dipublikasikan. Metode penelitian ini sebagai berikut:

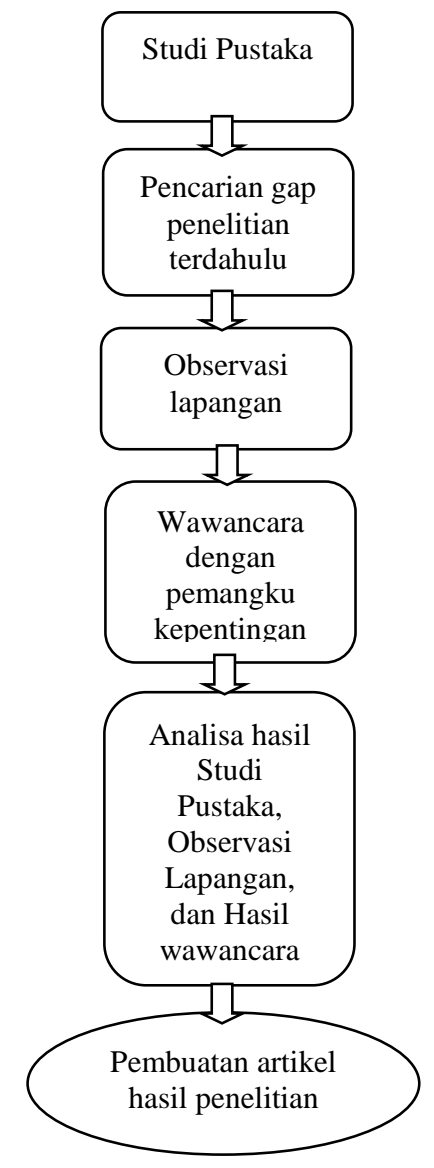

Gambar 1. Metode Penelitian

\section{PEMBAHASAN}

Permasalahan pengangguran dan daya saing sumber daya manusia menjadi tantangan yang nyata bagi Indonesia. Tantangan yang dihadapi Indonesia juga ditambah oleh tuntutan perusahaan dan industri. Bank Dunia (2017) melansir bahwa pasar kerja membutuhkan multi-skills lulusan yang ditempa oleh satuan dan sistem pendidikan, baik pendidikan menengah maupun pendidikan tinggi.

Berbagai program pemberdayaan masyarakat perbatasan telah dilakukan oleh pemerintah, salah satunya pemberdayaan masyarakat melalui Kementerian Sosial Republik Indonesia pada Program Keluarga Harapan dengan bantuan tunai bersyarat antara lain: 
Masyarakat Pra Sejahtera yang memiliki komponen Pendidikan (Anak usia sekolah SD, SMP Sederajat, dan SMA Sederajat), Bidang kesehatan (Anak usia dini dan Ibu Hamil), Disabilitas Berat dan Lanjut Usia. Tetapi semua program pemberdayaan dirasa belum dapat menyelesaikan persoalan. Berbagai tanggapan dan saran serta keinginan masyarakat perbatasan menginginkan sekolah lapang yang berbasis kewirausahaan agar dapat meningkatakan daya saing masyarakat perbatasan. Seiring berjalannya waktu, dengan dibukanya Sekolah Tinggi Ilmu Manajemen Shanti Bhuana Di Bengkayang menjadi angin segar bagi masyarakat Kabupaten Bengkayang khususnya masyarakat perbatasan. Selain masih langkanya perguruan tinggi dan hadirnya program studi kewirasuahaan dengan pembelajaran yang sistematis serta menghadirkan output berupa seorang sarjana Bisnis yang memiliki syarat untuk menjadi seorang sarjana tentunya harus memiliki unit usaha yang telah dijalankan dengan penghasilan minimal 50\% diatas Upah Minimum Kabupaten.

Program Studi Kewirausahaan memiliki tujuan untuk menciptakan pengusaha/wirausaha muda yang berjiwa kreatif, inovatif dan berbudaya amare (Budaya Amare adalah budaya ajaran Katolik yang diimplementasikan dalam ilmu bisnis tanpa berbuat curang dan saling menguntungkan, dimana menganggap semua orang yang terlibat adalah sama-sama ciptaan Tuhan yang harus saling dihormati dan saling mengasihi). Program pendidikan Dilakukan secara berkelanjutan selama masa sudi di kampus STIM Shanti Bhuana baik membuat bisnis hulu atau hilir sesuai dengan realitas modal yang dimiliki serta Selama mengerjakan proyek bisnis, mahasiswa didampingi dosen pembimbing yang kompeten dibidangnya. Agar kegiatan pendidikan berjalan dengan baik, perlu dibuatkan defenisi kewirausahaan menurut Program Studi Kewirausahaan Sekolah Tinggi Ilmu Manajemen Shanti Bhuana yaitu suatu sikap mental seseorang yang memiliki kreativitas, aktif, bercipta daya untuk membuat sesuatu yang unik dan baru serta bermanfaat bagi banyak orang melalui proses: mengembangkan, mengindentifikasi, dan mewujudkan visi dan misi dalam kehidupan berdasarkan Budaya Amare disertai tenggang waktu, modal, sumber daya dan juga risiko.

Program Studi Kewirausahaan Sekolah Tinggi Ilmu Manajemen Shanti Bhuana (STIM-SB) merancang keahlian para lulusan yang berkompetensi dengan mengacu pada Permendikbud No. 49/2014. Merujuk kualifikasi KKNI tersebut, maka pembelajaran di Program Studi Kewirausahaan STIM-SB dirancang untuk memberi perbekalan kepada mahasiswa agar:

1. Mampu mengidentifikasi peluang usaha, melakukan studi kelayakan usaha, dan membuat rencana bisnis secara inovatif dan kreatif, khususnya dalam menggali potensi komoditas dan pariwisata di aras lokal.
2. Mampu menjalankan bisnis mulai dari persiapan pasar, peluncuran produk, pengelolaan SDM dan keuangan

3. Mampu mengelola risiko-risiko bisnis dan mengembangkannya menjadi bisnis yang stabil dan bertumbuh.

4. Mampu berkomunikasi dan bernegosiasi.

5. Menguasai konsep inovasi dan prinsip-prinsip kreativitas dalam pengembangan usaha.

6. Menguasai pengetahuan pengembangan bisnis.

7. Menguasai dasar-dasar ilmu sosial dalam memahami lingkungan dan perkembangan bisnis.

8. Menguasai prinsip-prinsip ilmu manajemen.

9. Mengetahui dasar-dasar ilmu teknik, matematika dan statistik.

10. Memiliki tanggung jawab dan menunjung tinggi kode etik profesi

11. Memiliki jiwa kepemimpinan untuk membangun bangsa Indonesia

Selain untuk memenuhi kualifikasi diatas, penyelenggaraan Prodi Kewirausahaan STIM-SB diarahkan untuk menghasilkan lulusan dengan keunikan profil lulusan yang selalu berorientasi kepada semangatsemangat berikut:

1. Cinta tanah air: memiliki wawasan kebangsaan, memiliki nasionalisme yang sehat dan inklusif, serta bersemangat dalam membela negara.

2. Integritas: memiliki empati yang kuat, serta kepedulian untuk mengabdi dengan semangat projob, pro-poor, pro-environment, dan prodevelopment.

3. Profesionalitas: memiliki daya jual tinggi dengan keahlian yang jelas dalam bidang-bidang kajian yang dimiliki Sistem Informasi, ditunjang dengan sikap profesional sesuai dengan standar profesionalitas STIM-SB.

4. Budaya Amare sebagai gaya hidup dengan menjunjung tinggi nilai iman, kejujuran, dan moral.

Dari kualifikasi-kualifikasi di atas, agar dapat memberikan kontribusinya bagi pembangunan manusia/bangsa Indonesia, Program Studi Kewirausahaan STIM-SB berkomitmen untuk menghasilkan lulusan berdasarkan nilai-nilai yang dihayati oleh STIM-SB demi kepentingan ilmu pengetahuan dan profesionalitas serta mengacu pada kebutuhan peran entrepreneurship dalam masyarakat dan situasi pasar tenaga kerja saat ini dan yang akan datang.

Lulusan program Studi Kewirausahaan selain telah memiliki unit usaha dengan penghasil 50\% diatas Upah Minimum Kabupaten (UMK), juga memiliki integritas yang tinggi yang dapat dilihat dari peroleh ICP (Integrity Credit Point) setiap lulusan serta memiliki konsentrasi, antara lain: Bisnis Pariwisata dan Ketahanan Ekologi dengan kompetensi unggulan Bisnis Pariwisata Alam dan Bisnis Pariwisata Budaya, Bisnis Lintas Batas dan Ketahanan Ekonomi dengan kompetensi unggulan Bisnis 
Lintas Batas dan Keuangan Internasional, serta Bisnis Industri Kreatif dan Ketahanan Sosial dengan kompetensi unggulan Business Creation dan Home Industry.

Hadirnya lulusan Program Studi Kewirausahaan dapat membuka lapagan pekerjaan kepada lulusan SMK yang tidak memiliki pekerjaan serta menjadikan mereka sebagai Pelaku usaha yang memiliki jiwa entrepreneur secara inovatif dan kreatif dalam rangka mengembangkan kemampuan usaha atau mampu melihat peluang dengan semangat pro-job (penciptaan Lapangan Kerja), pro-poor (Pengentasanan Kemiskinan), proenviroment (kebijakan-kebijakan pro lingkungan), dan pro-development (pembangunan berkelanjutan). Pemimpin masa depan yang mempunyai kemampuan wirausaha melalui penguasaan teori kewirausahaan dan kemampuan praktik yang memadai, serta mampu bekerja sama secara efektif dalam tim dengan landasan Cinta tanah air, Integritas, Profesional, dan Budaya Amare, sehingga dapat menjadi pemimpin yang handal (trustworthy) baik dalam kelompok kecil maupun besar. Perencana yang cakap dalam perencanaan, dan pemberi masukan dalam proses kewirausahaan yang menjunjung tinggi etika dan moral, mau dan mampu berpartisipasi aktif dalam pembangunan dengan semangat cinta tanah air, integritas, profesionalitas, dan budaya Amare, Pemberi masukan agar fungsi organisasi dan kewirausahaan dapat berjalan dengan baik. Perancang dan pelaksana penelitian yang bersikap terbuka untuk terus berkembang dalam pengetahuan, keterampilan, dan keahlian dalam bidang kewirausahaan baik secara formal maupun non formal, serta mampu memberikan saran dan rekomendasi berdasarkan kaidah ilmiah. Pendorong masyarakat yang mampu merancang dan melaksanakan program pembinaan kewirausahaan sesuai kearifan lokal bagi masyarakat, dengan jiwa pengabdian yang disemangati rasa cinta tanah air, berintegritas tinggi, profesional, dan berbudaya Amare.

Peranan Program Studi Kewirausahaan yang terdapat di Perbatasan Kabupaten Bengkayang Kalimantan Barat tidak dapat berjalan dengan sendiri tanpa kerjasama dari berbagai pihak, baik masyarakat maupun pemerintah daerah dan pemerintah pusat. Bentuk dukungan pemerintah dapat ditindaklanjuti dengan pemberian beasiswa kepada masyarakat perbatasan untuk menempuh pendidikan pada program studi Kewirausahaan Sekolah Tinggi Ilmu Manajemen Shanti Bhuana serta pemberian beasiswa studi lanjut kepada dosen yang sedang melanjutkan pendidikan serta perbaikandan peningkatan sarana dan prasarana pendukung seperti pembuatan dan peningkatan jalan akses menuju kampus serta perbaikan jaringan telekomunikasi dan saluran air PDAM untuk keperluan kampus dan masyarakat sekitarnya serta mengirimkan para Aparatur Sipil Negara (ASN) Pemerintah Kabupaten Bengkayang untuk melanjutkan studi pada Program Studi Kewirausahaan.
Secara nyata penyelenggaraan pendidikan pada Program Studi Kewirausahaan STIM Shanti Bhuana sangat selaras dengan kearifan lokal dan tujuan pembagunan nasional. Hal ini terlihat pada gambar kegiatan mahasiswa yang secara rutin dilakukan dari berbagai kegiatan praktik yang dilakukan oleh mahasiswa selama studi secara rutin dan berkelanjutan pada program studi kewirausahaan STIM Shanti Bhuana Bengkayang seperti terlihat pada gambar-gambar kegiatan mahasiswa sebagai berikut.

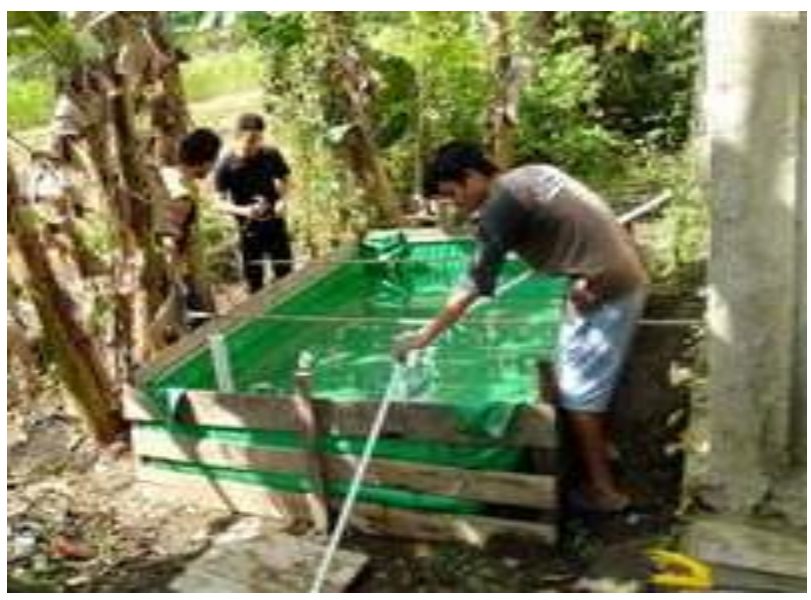

Gambar 2. Praktik Bisnis Ternak Lele

Gambar diatas merupakan salah satu kegiatan praktik bisnis mahasiswa dengan memanfaatkan pekarangan rumah untuk menciptakan dan mendapatkan sumber pendapatan tambahan bagi keluarga yang merupakan bagian dari bisnis keluarga dan usaha kecil. Selain pemanfaatan pekarangan rumah sekaligus sebagai bentuk implementasi konsep pembangunan yang berkelanjutan (sustainable) serta ramah lingkungan dalam kaitanya terhadap konsep ekonomi biru (blue economics) dan ekonomi hijau (green economics).

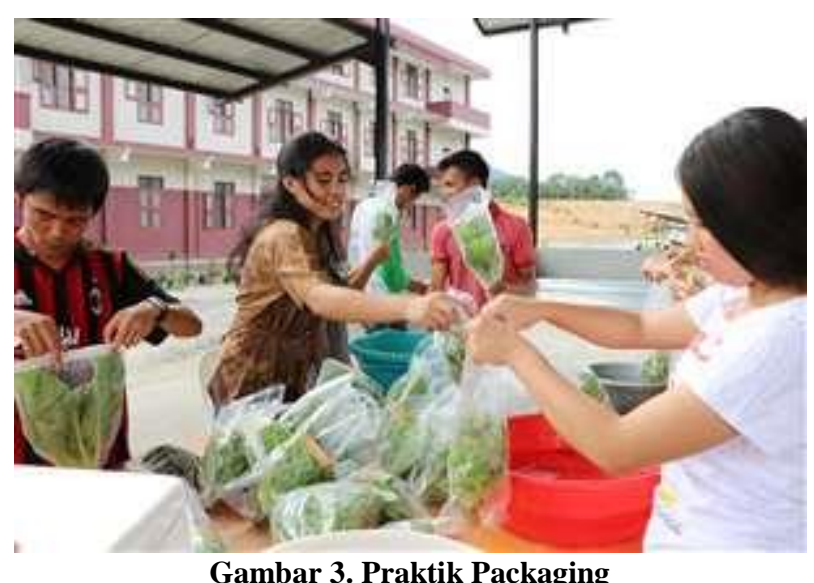

Gambar 3. Praktik Packaging

Gambar 3 di atas merupakan salah satu kegiatan praktik packaging untuk melatih mahasiswa dalam pengemasan produk dengan konsep yang sederhana tetapi dapat memberikan nilai tambah bagi produk serta 
dikembangkan secara berkelanjutan untuk pengemasan yang ramah lingkungan, kedepannya konsep packaging yang dilakukan adalah dengan memanfaatkan teknologi sesuai perkembangan zaman berbasiskan ramah lingkungan.

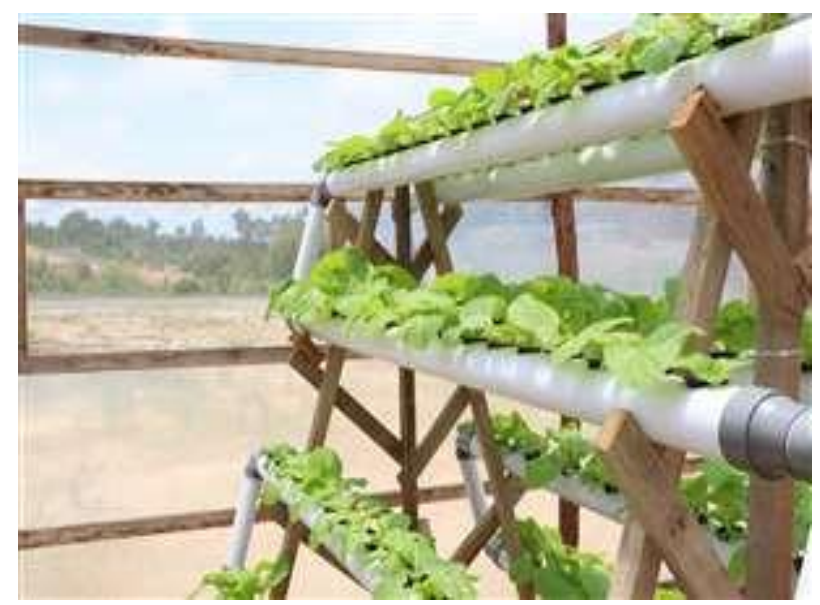

Gambar 4. Lab. Praktik Bisnis Hidroponik

Laboratorium merupakan salah satu kunci suksesnya penyelenggaraan pendidikan tinggi, dimana teori dapat diaplikasikan secara langsung melalui kegiatan praktik di laboratorium. Laboratorium kebun hidroponik merupakan salah satu dari laboratorium penunjang kegiatan praktik pada program studi kewirausahaan STIM Shanti Bhuana. Selain mengajarkan mahasiswa untuk berwirausaha dengan konsep yang ramah lingkungan juga sebagai bentuk dukungan agar setiap unit usaha mahasiswa maupun kelak sebagai lulusan menghasilkan produk-produk ataupun bisnis yang berorientasi pada kesehatan dan secara tidak langsung sebagai motivator serta penggerak penggunaan produk non kimiawi yang dapat merusak kesehatan dan keberlangsungan hidup yang berkaitan dengan pertumbuhan ekonomi biru (blue economics) dan pertumbuhan ekonomi hijau (green economics).

\section{KESIMPULAN}

Pentingnya program Studi Kewirausahaan dalam menghadapi Era 4.0 di Perbatasan Kabupaten Bengkayang dengan Sarikin Negara Bagian Sarawak Malaysia sebagai upaya mensejahterakan masyarakat melalui pendidikan berbasis kewirausahaan.

Tingginya angka pengangguran yang berasal dari Sekolah Menengah Kejuruan (SMK) menduduki peringkat teratas yaitu sebesar $9,27 \%$ disebabkan karena tidak tergalinya semangat wirausaha bagi pelajar SMK dan sulitnya mencari perguruan tinggi yang menyelenggarakan program studi kewirausahaan.

Program Studi Kewirausahaan sebagai solusi serta langkah tepat dalam mempersiapkan generasi muda menghadapi Era 4.0 disamping program pemberdayaan masyarakat baik melalui Program Keluarga Harapan, PAMSIMAS, Dana Desa serta Program Lainnya yang secara nyata tidak mengedukasikan masyarakat untuk bisa lebih mandiri dan memiliki jiwa wirausaha.

Program Studi Kewirausahaan sejalan dengan visi dan misi pembangunan 2015-2019 Terwujudnya Indonesia yang Berdaulat, Mandiri, dan Berkepribadian Berlandaskan Gotong-royong. Serta sesuai dengan citacita pembangunan Kabinet Indonesia Maju 2019-2024 melalui Sumber Daya Manusia (SDM) Maju, Indonesia Unggul.

\section{SARAN}

Untuk mendukung Program Studi Kewirausahaan, pemerintah diharapkan dapat membantu perguruan tinggi meningkatkan sumber daya manusia (dosen) kewirausahaan dengan menyediakan beasiswa tanpa syarat kepada semua dosen Program Studi Kewirausahaan agar dapat meningkatkan kualitas pembelajaran terkait kewirausahaan. Serta beasiswa masyarakat perbatasan untuk melanjutkan perkuliahan pada program studi kewirausahaan STIM Shanti Bhuana Bengkayang dan melibatkan para dosen daam kegiatan pelatihan dan workshop kewirausahaan di perbatasan Jagoi Babang dan Kabupaten Bengkayang secara umum.

\section{DAFTAR PUSTAKA}

Alfarisi, M.S. 2018. IPTEK Bagi Masyarakat: Penerapan IoT Dengan Smartphone Pasa SMK Plus AlMusyarrofah Sebagai Upaya Pencapaian Sustainable Development Goal Tujuan 4 Target 3. Sebatik, 22 (2), 107-110.

Agung, I. 2012. Kajian Penyelenggaraan Pendidikan Di Daerah Perbatasan. Jurnal Ilmiah VISI P2TK PAUD NI, 7 (2), 173-184.

Beni, S. \& Manggu, B. 2018. Program Keluarga Harapan Dalam Menumbuhkan Jiwa Wirausaha. Jurkami 3 (2), 150-160.

Dally, I.A. 2018, Revolusi Industri 4.0: Dampak dalam Berbagai Aspek, Fakultas Ekonomi dan Bisnis Universitas Indonesia.

Hoedi, P., \& Wahyudi, S. 2018 Industri 4.0: Telaah Klasifikasi Aspek dan Arah Perkembangan Riset, Jurnal Teknik Industri Universitas Diponegoro, 13 (1), Januari 2018.

Kurniawan, A.H. \& Tunggul. B. 2019. Evaluasi ELearning STMIK Sentra Pendidikan Bisnis Airlangga Samarinda. Sebatik, 23 (1), 65-71.

Schwab, K. 2017. The Fourth Industrial Revolution. https://doi.org/10.17226/24699

Sadewo, Y.D. 2017. Entrepreneurship Education in Border As the realization of National Development and National Resilience. Sekolah Tinggi Ilmu Manajemen Shanti Bhuana, Bengkayang.

Sadewo, Y.D. 2017. Hambatan Dan Tantangan Program Studi Kewirausahaan Di Wilayah Perbatasan. Sekolah Tinggi Ilmu Manajemen Shanti Bhuana, Bengkayang. 
Wibowo, A. 2011. Pendidikan Kewirausahaan (Konsep dan Strategi), Yogyakarta: Pustaka Pelajar.

Yahya, M. 2018, Era Industri 4.0: Tantangan dan Peluang Perkembangan Pendidikan Kejuruan Indonesia, Pidato Pengukuhan Penerimaan Jabatan Professor Tetap dalam Bidang Ilmu Pendidikan Kejuruan Fakultas Teknik Universitas Negeri Makassar. Tanggal 14 Maret 2018.

\section{UCAPAN TERIMA KASIH}

Publikasi ini dibiayai oleh

Direktorat Riset dan Pengabdian Masyarakat Dirjen

Penguatan Riset dan Pengembangan Kementerian Riset,

Teknologi, dan Pendidikan Tinggi sesuai dengan

Kontrak Hibah PDP Tahun Pelaksanaan 2019. 